\begin{tabular}{|c|c|c|c|c|c|}
\hline First contact & $\begin{array}{l}\text { Strongly } \\
\text { agree }\end{array}$ & $\begin{array}{l}\text { Somewhat } \\
\text { agree }\end{array}$ & Not sure & $\begin{array}{l}\text { Somewhat } \\
\text { disagree }\end{array}$ & $\begin{array}{l}\text { Strongly } \\
\text { disagree }\end{array}$ \\
\hline $\begin{array}{l}\text { 1. When your Primary Care Practice is closed, is there a phone number you can } \\
\text { call when you get sick? }\end{array}$ & 5 & 4 & 3 & 2 & 1 \\
\hline $\begin{array}{l}\text { 2. When your Primary Care Practice is closed on Saturday and Sunday and you } \\
\text { get sick, would someone from there see you the same day? }\end{array}$ & 5 & 4 & 3 & 2 & 1 \\
\hline $\begin{array}{l}\text { 3. When your Primary Care Practice is closed and you get sick during the night, } \\
\text { would someone from there see you that night? }\end{array}$ & 5 & 4 & 3 & 2 & 1 \\
\hline Longitudinality & $\begin{array}{l}\text { Strongly } \\
\text { agree }\end{array}$ & $\begin{array}{l}\text { Somewhat } \\
\text { agree }\end{array}$ & Not sure & $\begin{array}{l}\text { Somewhat } \\
\text { disagree }\end{array}$ & $\begin{array}{l}\text { Strongly } \\
\text { disagree }\end{array}$ \\
\hline $\begin{array}{l}\text { 1. Does your Primary Care Physician (PCP) give you enough time to talk about } \\
\text { your worries or problems? }\end{array}$ & 5 & 4 & 3 & 2 & 1 \\
\hline 2. Do you feel comfortable telling your PCP about your worries or problems? & 5 & 4 & 3 & 2 & 1 \\
\hline $\begin{array}{l}\text { 3. Does your PCP know you very well as a person, rather than as someone with } \\
\text { a medical problem? }\end{array}$ & 5 & 4 & 3 & 2 & 1 \\
\hline 4. Does your PCP know what problems are most important to you? & 5 & 4 & 3 & 2 & 1 \\
\hline 5. Does your PCP know your complete medical history? & 5 & 4 & 3 & 2 & 1 \\
\hline Coordination & $\begin{array}{l}\text { Strongly } \\
\text { agree }\end{array}$ & $\begin{array}{l}\text { Somewhat } \\
\text { agree }\end{array}$ & Not sure & $\begin{array}{l}\text { Somewhat } \\
\text { disagree }\end{array}$ & $\begin{array}{l}\text { Strongly } \\
\text { disagree }\end{array}$ \\
\hline 1. Have you ever had a visit to any kind of specialist or special service? & & Yes & & No/Not sure & \\
\hline 2. Did your PCP suggest you go to the specialist or special service? & 5 & 4 & 3 & 2 & 1 \\
\hline 3. Did your PCP discuss with you different places you could have gone to get & 5 & 4 & 3 & 2 & 1 \\
\hline
\end{tabular}


help with that problem?

4. Did your PCP or someone working with your PCP help you make the appointment for that visit?

5. Did your PCP write down any information for the specialist about the reason for the visit?

6. Does your PCP know what the results of the visit were?

Comprehensiveness (services available)

For each one, please indicate whether it is available at your PCP's office.

1. Counseling for mental health problems

2. Changes in mental or physical abilities that are normal with getting older

3. Counseling related to dementia

4. Counseling related to abuse

5. Counseling related to personal preferences about end of life issues

Comprehensiveness (services provided)

In visits to your PCP, are any of the following subjects discussed with you?

1. Advice about appropriate exercise for you

2. Advice about regular bowel movements

3. Advice about over-the-counter medications

4. Advice about medical information in the media: on TV, in the newspaper, etc.

5. Advice about a healthy balance of work and rest

\section{Community orientation}

\section{5}

4

3

2

1

$\begin{array}{lllll}5 & 4 & 3 & 2 & 1\end{array}$

5

Strongly

4

3

1

Somewhat

Somewhat Strongly

agree

agree

(3)

disagre

disagree

(2)

\begin{tabular}{lllll}
5 & 4 & 3 & 2 & 1 \\
5 & 4 & 3 & 2 & 1 \\
5 & 4 & 3 & 2 & 1 \\
5 & 4 & 3 & 2 & 1 \\
5 & 4 & 3 & 2 & 1 \\
\hline
\end{tabular}

$\begin{array}{ccccc}5 & 4 & 3 & 2 & 1 \\ \text { Strongly } & \text { Somewhat } & & \text { Somewhat } & \text { Strongly }\end{array}$

\section{Community orientation}

1. Does anyone at your PCP's office ever make home visits?

2. Does your PCP know about the important health problems of your community?

5

5

5

agree

disagree disagree

$\begin{array}{llll}4 & 3 & 2 & 1 \\ 4 & 3 & 2 & 1 \\ 4 & 3 & 2 & 1 \\ 4 & 3 & 2 & 1 \\ 4 & 3 & 2 & 1\end{array}$

$\begin{array}{ccccc}5 & 4 & 3 & 2 & 1 \\ \text { Strongly } & \text { Somewhat } & & \text { Somewhat } & \text { Strongly } \\ \text { agree } & \text { agree } & \text { Not sure } & \text { disagree } & \text { disagree }\end{array}$

5

4

5

5

3

43

2

1


3. Does your PCP get opinions and ideas from people that will help to provide better health care?

4. Does your PCP investigate whether the available health care is meeting the needs of the community? 